\title{
REDD+ Governance, Benefit Sharing and the Community: Understanding REDD+ from Stakeholders' Perspective in Nepal
}

\author{
(Perspective) \\ Govinda Paudel* and Rabul Karki* \\ * ForestAction Nepal \\ Corresponding author: paudelg@gmail.com
}

\section{INTRODUCTION}

Reducing Emission from Deforestation and Forest Degradation, including conservation and sustainable management of forest and enhancement of forest carbon stock (REDD+) is a climate change mitigation strategy which aims to offer financial incentive to forest stewards for their contribution to forest management and carbon stock enhancement. REDD + has successfully created a global excitement (Angelsen and McNeill 2012), which, in turn, has raised optimism at national level, at least during the initial phases (Khatri and Paudel 2013). Also, there has been a rapid proliferation of activities at national as well as at international level aimed at reducing deforestation and forest degradation (Silori et al. 2013). This is partly due to high level of expectations that people had from REDD+ in reducing emissions and improving livelihoods of forest-dependent communities. In Nepal, such expectations have attracted stakeholders to engage with REDD+ initiatives.

Yet, there have been diverse opinions and views on the REDD+ mechanism. It is thought to be a viable option for addressing climate change. First, it is one of the cheapest options for tackling climate change (Stern 2006) and an effective climate strategy in 'making live trees more valuable than the dead ones' (Angelsen et al. 2012). Second, emissions in one place can be offset by carbon enhancement elsewhere
(Skutsch and DeJong 2010). Third, in addition to carbon benefits, it contributes to generate co-benefits such as social benefits (e.g. poverty reduction, community development) and noncarbon benefits (e.g. ecological) (Busch et al. 2010). Finally, it fosters collaboration in the fight against climate change, while facilitating huge financial flow from developed and developing countries (Angelsen and McNeill 2012).

Despite such assertions about REDD+, international negotiations have not yet come to a consensus on its institutional mechanism, including financing, implementation and benefit sharing (Angelsen et al. 2012). REDD+ has become increasingly complex (Angelsen et al. 2012) and, therefore, realizing REDD+ outcomes is neither fast nor easy (Hansen $e t$ al. 2009). Scholars have argued that it threatens community autonomy (Phelps et al. 2010), local people's access to forests (Graham 2012), community livelihood, biodiversity and provision of ecosystem services (CBD 2010). To the extreme, REDD+ has been perceived as ' $\mathrm{CO}_{2}$ lonialism ${ }^{1}$ of forests' with false hope and empty promises and consequently generating negative results for the people, politics and climate (Goldtooth 2010).

Some pertinent questions around REDD+ have recently been raised. These include (i) Are

${ }^{1}$ Advocates of indigenous people's right have coined a term ' $\mathrm{CO}$ lialism' for referring REDD+ as a recent manifestation of 'colonialism'. In this view, REDD+ is a ' $\mathrm{CO}_{2}$ lonialism' - capitalism of the trees and air (Goldtooth, 2010, p.13). 
the stakeholders optimistic, pessimistic or indifferent towards REDD+?; (ii) Do they see a possibility of benefiting from carbon as well as non-carbon incentives?; (iii) How do REDD+ benefits trickle down to the forest stewards, e.g. communities?; and (iv) How could the benefits be distributed? Both theoretical and empirical studies have shown that the knowledge of REDD+ amongst the stakeholders at present is not sufficient (Romijn et al. 2012) to answer these questions. However, Purnomo et al. (2012) argue that communities managing forests can independently decide whether REDD+ is necessary only when they have adequate knowledge, power and leadership. Therefore, searching answers to these questions becomes important.

Amidst such global debate, Nepal has initiated readiness process by developing Readiness Preparation Proposal (RPP) in partnership with the World Bank's Forest Carbon Partnership Facility (FCPF). The REDD+ process is coordinated by the REDD Forestry and Climate Change Cell (REDD Cell). Besides implementation of RPP with financial support from FCPF, a number of other projects and initiatives such as research and studies, capacitybuilding activities, piloting REDD+ project, workshops and sharing at national and international fora are being undertaken to support the readiness process. Along with this, the preparation of National REDD+ Strategy is underway. In these initiatives, a number of stakeholders, including Government of Nepal (GoN), academics, researchers, donor and international organizations, federations and networks, freelance consultants and media are actively engaged. It has been crucial in facilitating debates on REDD+ and forging partnerships and collaborations to synergize their efforts, for which greater understanding of perspectives has been crucial.

To fulfil this gap, the authors conducted brief interviews with 11 stakeholders who were engaged in the REDD+ initiatives in Nepal. These actors were selected on the basis of their involvement and expertise in REDD+. Their ideas and perspectives have been synthesized and brought to the forefront of discussion. Primarily, professionals from GoN, academic institutions, international organizations, federations and networks were interviewed, in addition to freelance media persons. To focus the discussion during interviews, facilitate articulation of opinions of interviewees, and organize, synthesize and distil information, four questions were asked: (i) What do you think about the relevance of REDD+ in Nepal, particularly in the context of community forestry? (ii) Does the current REDD+ process address the issues raised around REDD+ so far? (iii) What should be the financing mechanism and basis of payment system?; and (iv) What do you suggest to make REDD+ beneficial to communities? Face-to-face interviews, email communication and telephone conversations were carried out in order to collect the views of the interviewees.

The responses were organized, summarized and shared with the interviewees concerned to make sure that their views are articulated appropriately. The second section of the paper presents the responses and views of the individual interviewees, while the final section presents a brief synthesis of the responses.

\section{STAKEHOLDERS' PERSPECTIVE ON REDD+ PROCESS}

\section{Narendra Chand, REDD Forestry and Climate Change Cell, Ministry of Forests and Soil Conservation}

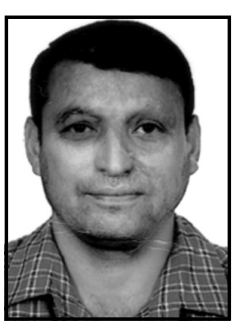

REDD+ can be beneficial to Nepal if we are able to get payment for both carbon and non-carbon credits. However, the success of REDD+ largely depends on how successfully we address the issues of deforestation and forest degradation. For this, substantial 'behavioural change' is essential among the actors involved in the REDD+ process. If this really happens, 
REDD+ will also contribute significantly to the country's biodiversity or sustainable forest management efforts. Existing political instability, however, may pose a great threat to planned actions against deforestation.

The current REDD+ initiatives have tried to make the REDD+ process inclusive and participatory. However, it is widely acknowledged that the REDD+ actors are neither fully prepared nor have the capacity to take on emerging challenges. Strategic actions that are expected to address deforestation/forest degradation are not in place. Though we are striving to address the concerns of all stakeholders, it is becoming increasingly difficult to take into consideration the aspirations of diverse actors.

Regarding the REDD+ financing mechanism, a hybrid of what is being practised in the government and the trust fund can be a feasible option to ensure funds reach the forest users efficiently and in a transparent manner. The forest users should be paid on the basis of carbon enhancement, carbon retention, non-carbon (ecological) services and biodiversity conservation.

The REDD Cell will play a coordinating role amongst the REDD actors, including the government agencies concerned. The cell will also take part in designing REDD+-related policies. Engagement in REDD+ discussions and lobbying for the REDD+ payment mechanism at international level can be a likely role for the REDD Cell in the future.

Bharat K Pokharel, HELVETAS Swiss Inter-cooperation Nepal

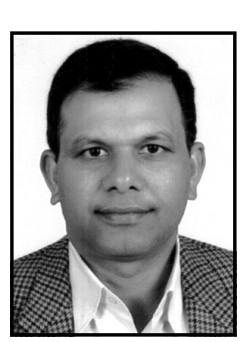

Looking at the current discourse on REDD+ and its impact on ground, it does not seem to be beneficial to forestdependent communities as expected. Whether REDD+ is relevant in Nepal or not depends on how it is linked with the community-based forestry regimes and the extent of tenure rights that local communities and private forest- and tree-owners can enjoy, and the type of policy and legal frameworks of the national and local governments for recognizing the role of local communities and private land owners in forest management and restoration. In and around community forest areas, it is clear that local communities, private land holders and government cannot afford to meet all the requirements of REDD+ in terms of meeting the conditions of additionality, permanence, leakage, scientific measurements and technical knowledge. It also does not seem to be relevant even in non-community forest areas in the Terai region because it cannot meet the objectives of REDD+, which is to create new forest areas to increase the forest cover and density and reduce the rate of deforestation and forest degradation. Only devolution can meet the objectives of REDD+. However, real devolution can only happen with accountable, democratic and propoor government at the centre. With the current mixed electoral system (i.e., majority election and proportional representation systems), the chance of having any stable government is remote. Therefore, an effective REDD+ also seems a remote possibility in Nepal. However, voluntary market and continuation of development cooperation in forestry and climate sectors in Nepal for some time can perhaps be an option. As far as the role of our institution is concerned, internationally we have been engaged with our development partners and government delegates to make the REDD+ policy in favour of forest-dependent poor and local communities. In Nepal, we have been supporting government, local communities, private sector actors, school teachers, children, youth clubs and farmers to implement national and local-level adaptation plans and raise their awareness of the possible cost and benefits of both climate mitigation and adaptation measures. It is up to them to choose the activities in which they would like to be 
involved. Our organization, nevertheless, has realized that Nepalese farmers and local communities could benefit more if they invest their time and energy in climate adaptation measures.

\section{Bhaskar Karky, International Centre for Integrated Mountain Development (ICIMOD)}

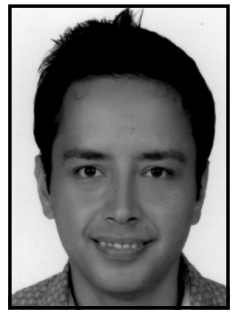

In theory, REDD+ is relevant in Nepal; however, in practice we do not yet know its relevancy. The rules, agreements and policies by and large will determine the applicability and feasibility, which are yet to be ascertained. Nevertheless, we have some preconceptions about how and on what basis the REDD+ payment should be. REDD+ payment should be on the basis of two major criteria: carbon and population density. This is also what we've observed through the learning from the pilot project. REDD+ payment is neither a poverty reduction nor a social uplift programme. The investor is solely interested in the payment generating incentive for increasing the carbon stock. There is a need for putting in much more efforts by all sides to work out a common, feasible and sustainable mechanism for implementing REDD+ that meets its intended objectives. As a regional learning platform that shares new knowledge between the regional REDD+ stakeholders, ICIMOD will provide technical backstopping to its regional member countries and their focal points to pilot and test the REDD+ initiatives and share their lessons on what worked and what did not.

\section{Santosh Rayamajhi, Institute of Forestry (IoF), Pokhara}

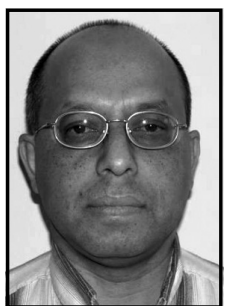

REDD+ is very much relevant in Nepal as a payment mechanism so as to support forest management initiatives that are being carried out either by the government or by local communities. It can serve as a strong motivational factor to both conservation and expansion of forests in Nepal. The primary basis of REDD+ payment should be the additionality of carbon sequestration as compared to the base situation. To make REDD + a success, a national-level REDD+ fund should be established based on the national forest coverage and payment should be allocated according to the estimate of carbon sequestration by different types of forests. The Ministry of Forests and Soil Conservation and its Departments have to be mobilized to take the stock of the base year carbon and carry out periodic inventory through a combination of modern technology, including GIS tools and LiDAR-based forest inventory, and on-theground survey. Additional efforts should be directed at strengthening and institutionalizing the role of forestry field staff for monitoring, capacity building, field research and documentation. In this connection, IoF as an academic institution, may have three distinct roles. These include (i) Orient and train new cadre of foresters and in-service staff in the concept, theory and process of REDD+, (ii) Conduct research for establishing baseline, methods, process and benefit sharing 
mechanism as well as offer policy feedback, and (iii) Disseminate research findings, national policy implications and process mechanisms of REDD+ through seminars, workshops and publications.

\section{Apsara Chapagain, Federation of Community Forestry Users Nepal (FECOFUN)}

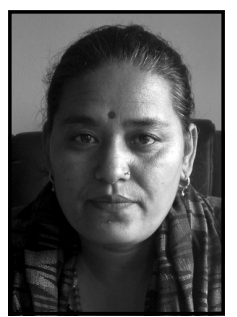

We carried out REDD+ piloting in three districts and have been conducting awarenessraising programmes in 16 districts. During project implementation, in both cases, we realized that not only the basic objectives but also the major activities of community forestry and REDD+ match to some extent. For example, the activities carried out under the REDD+ projects such as forest management and alternative energy promotion have already been carried out by communities as part of community forestry development activities. Therefore, REDD+ might add value to the community forestry activities, particularly in managing forest. Nevertheless, I don't think that it will create a lot of changes, but it will support sustainable forest management activities.

Looking at Nepal's negotiation power and the level of incentive that the community forest user groups would enjoy, it is still doubtful whether the real forest stewards will receive fair benefits. Also, the major question remains whether a policy conducive to transforming tenure rights will be designed or not. There are still unclear and dubious tenure rights over forest products, carbon and other environmental services, as the state still owns forestland, while the communities have been utilizing forest resources. In addition, there are questions to be addressed so that the benefits will be shared fairly within the group. More attention is required to address the issues of the poor and the marginalized.

The government has been putting efforts in terms of formulating a policy and programme in the course of preparing Nepal for REDD+. However, by looking at the past experience of policy processes, there are still questions whether the current policy process is democratic and inclusive enough in formulating a fair and equitable REDD+ policy. Similarly, in the implementation side, the REDD+ activities led primarily by the government have rarely been decentralized in the real sense. As a responsible institution, FECOFUN always carries out its activities by keeping forest user groups at the centre. There is need for space for FECOFUN in all REDD+ processes as it is the umbrella organization of community forest users in Nepal. Besides, FECOFUN has a significant role in coordination and consultation with forest users and dissemination of REDD+ information to them.

\section{Rama Ale Magar, The Himalayan Grassroots Women's Natural Resource Management Association (HIMAWANTI)}

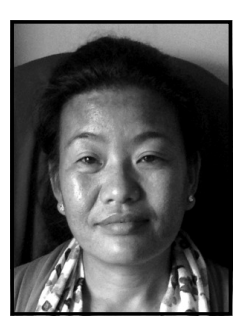

In the current scenario at national level, stakeholders are aware of, and have a high level of expectation from, and dedication to, the REDD+ scheme. The REDD+ initiative is positive in the sense that the stakeholders are aware, capable and dedicated towards it. However, policy formulation and implementation of REDD+ scheme is not as easy as perceived by many stakeholders. Immediate attention and greater clarity are needed in various dimensions such as how to receive REDD+ payments from the developed countries. 
The REDD+ strategy formulation process needs to be inclusive and participatory in such a way that all stakeholders concerned, particularly women, should be able to participate in some way or the other. For this, a few issues need to be clarified: language should be simple and comprehensible to everybody, and a proper monitoring mechanism should be in place. Similarly, the policy should also guide the formulation of a fair benefit sharing mechanism at local level. Also, the basis of payment should include representation of women and Dalits ${ }^{2}$, as suggested by the pilot project conducted during the last four years. The design of the payment mechanism should avoid too many layers so as to keep it simple and efficient. It is important to provide spaces for the organizations of women and the marginalized in the payment mechanisms, including carbon trust fund distribution committee, so as to ensure effective and fair implementation of REDD+ from their perspectives. With the aims to promote women's participation in REDD+ initiatives and to ensure their forest rights, HIMWANTI Nepal is engaged in networking, lobbying and advocacy.

\section{Pasang Dolma Sherpa, Nepal Federation of Indigenous Nationalities (NEFIN)}

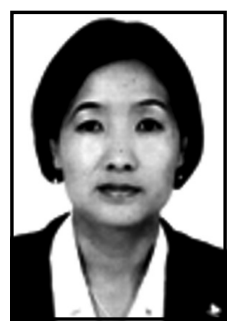

Indigenous peoples have a symbiotic relationship with forest, land and other natural resources for their livelihoods and identity. Therefore, REDD+ would be relevant in Nepal only if it adequately addresses the concerns and issues of indigenous peoples and other forestdependent communities by ensuring and recognizing their traditional customary law, practices, and knowledge system.
The Government of Nepal is working on developing the national REDD+ strategy in Nepal and also implementing their programs. In this process, it is a crucial time for indigenous peoples for their full and effective participation in the whole process of developing relevant policies and programs. Therefore, the concerned Government agencies, other relevant stakeholders including bilateral and multilateral agencies, donors and non-governments organizations will need to address the issues and concerns of indigenous peoples', particularly their rights of continuing traditional livelihoods system enshrined by international treaty and convention like ILO C 169 and UNDRIP in Nepal. It is also pertinent for them to support and cooperate for developing the capacity and awareness level of indigenous peoples for their meaningful participation and engagement in the process of REDD+ and other relevant policies and programs to contribute for sustainable management of forest and livelihoods in Nepal.

\section{Sunil Pariyar, Dalits Alliance for Natural Resources (DANAR), Nepal}

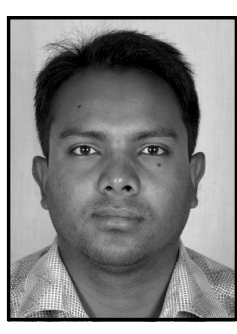

REDD+ implementation is not expected to make much difference to the poor and Dalit communities in Nepal. Dalit communities are mostly dependent on forest resources for their livelihoods. However, in many cases, they have been deprived of their right to access forest resources despite the implementation of the community forestry programme. This has been particularly due to lack of a policy provision that exclusively promotes Dalit participation in the policy process and secures their rights over forest resources. Also, in a situation when the entire community forestry institution has been facing the accusation of weak governance, the issue of benefiting the poor and Dalit communities

${ }^{2}$ Dalits are the oppressed communities who are often considered as untouchable class of society. 
through the REDD+ mechanism is dubious. Without addressing the issues of exclusion, discrimination, exploitation, inequity and domination at grass roots level in community forestry, REDD + may not be beneficial for Dalit communities and in the long run the REDD+ scheme itself may fail to fulfil its basic objectives.

If a policy and legal framework are formulated for REDD+ and implemented in such a way that Dalit participation is promoted and their forest rights are secured in practice, then only will a scheme like REDD+ be beneficial to Dalit communities. Also, a strong monitoring, reporting and verification (MRV) mechanism for social safeguards at local level is imperative. Moreover, there needs to be adequate consultations among relevant stakeholders before designing any payment mechanism. Nevertheless, the role of civil society organizations (CSOs) as a watchdog might be useful while the government coordinates, owns and implements the whole range of REDD+ initiatives.

REDD+ would be effective if the supporting agencies, including donors, through their ongoing initiatives, give due consideration to Dalit communities and put efforts on issues of inclusion, capacity building and advocacy together. In this situation, DANAR's role would be to advocate for Dalits' rights.

Ram Rup Kurmi, Association of Collaborative Forest Users of Nepal (ACOFUN)

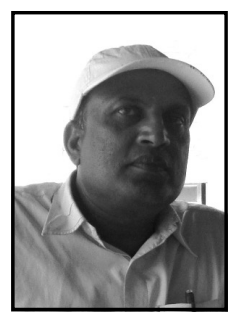

REDD+ is relevant only if the government and stakeholders have the exact translation of the principles of REDD+ in order to improve forest governance and address deforestation and forest degradation. However, REDD+ implementation seems to be a challenging task as long as the issue of elite capture over resources exists. As there are different forest management modalities in Nepal, there should be a different REDD+ payment mechanisms for each forest management regime. More payment should be done in areas where high level of efforts is needed to curb deforestation, improve governance and to ensure rights of local forest managers. The carbon-centric payment should be focused only on those areas where conservation of forest is necessary and enhancement of carbon stock is possible. While designing a payment mechanism, local stakeholders' investment and role should be recognized and respected. While a multi-stakeholder committee should be formed to govern the REDD+ payments, the Ministry of Commerce and Supplies and the local government should be given the coordinating role at national and local level respectively. There is need for significant change in the structure of the REDD Cell and the processes it follows to make the REDD+ preparation initiatives more inclusive and participatory.

As we all know, there are several issues related to the Terai forest management and the government has not been serious in this. ACOFUN was established to address some of the pertinent issues in Terai forest management. It aims to establish local peoples' rights over forest resources by handing over forests to the Terai dwellers that are prevented from exercising their rights. In this context, ACOFUN has been advocating for policy change at national level and capacity building for forest management and awareness raising on REDD+ at grassroots level in the Terai. It has also been trying to be the part of various policy fora with an aim to contribute to ensuring equitable benefits. 
Kapil Adhikari, Federation of Forestbased Industries and Trade (FenFIT)

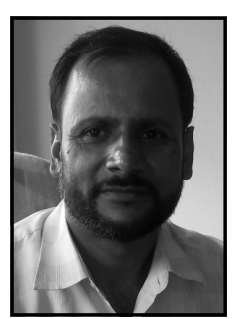

REDD+ is more important for industrialized countries, as they are required to reduce their emission levels through this mechanism. But for developing nations, where large numbers of people are living in poverty, utilization of natural resources, for instance water and forest, would be more important than REDD+. REDD+, in other ways, is a domination of developed countries over the developing. If the income through sustainable management of forest exceeds that from REDD+, then why should we choose the latter?

Though REDD+ looks fine in principle, it is yet to demonstrate value addition to the existing forest management and forest-based economy.

Before talking about a fair REDD+ benefit sharing mechanism within the country and communities, a cost-benefit analysis should be carried out to see whether the payment of REDD+ implementation would exceed its cost. If REDD+ seems to be beneficial, then an inclusive multi-stakeholder process may be designed and initiated to allow other stakeholders to raise their concerns and own the process where government can play a coordinating and facilitating role. Regarding a payment system for REDD+ incentive, establishing a separate fund would perhaps be a better option. Such fund could be managed by a multi-stakeholder mechanism, including government, at two levels: one at national level and another at district level. The district level mechanism may be effective to monitor the grassroots-level REDD+ activities and to ensure the real forest right holders receive the payment.

FenFIT always has its own stance of scientific and sustainable management of forest because it is imperative also for the existence and sustainability of forest entrepreneurs.

\section{Krishna Murari Bhandari, Freelance Journalist}

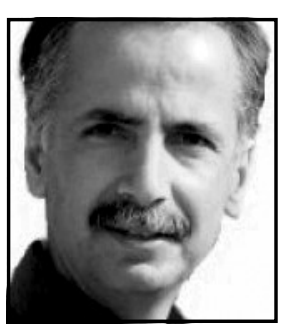

REDD+ is something that Nepalese may receive in the form of bonus. However, this does not mean one will receive it for free. There are liabilities and costs associated with it. Whatsoever, it should be planned in such a way that it benefits the real forest managers. Analysis of country's economic and poverty conditions should be considered as one of the prioritized agenda while formulating a REDD+ policy. Though embarking on REDD+ would not require any financial cost for Nepal, measures should be applied carefully while adopting its activities.

There is a famous saying in Nepali "Kaam garne kaalu, Makai khane bhalu" (nearest English translation: one enjoys benefits over the work of another). Should this happen in the case of REDD+, it would not benefit the country. To make sure the benefits are shared fairly and equitably at local level, there are different ideas and mechanisms being discussed at international and national level. However, there are risks associated with each one of them. For this, communication and other skills and techniques matter. Looking at the present development trend in Nepal, there is a high probability that only $10-15$ percent of the fund might reach the community, while the rest being spent on administrative purpose. A nationallevel payment mechanism through the government machinery may not be fully trusted, as we have seen inefficiency and corruption. On the other hand, if private sector middlemen or brokers are involved in the REDD+ process, which is highly likely, the lion's share of the 
money may go as part of their service charge and transaction cost. This situation has been very much apparent in the agriculture sector of Nepal, where local farmers have been victim of middlemen's game. We cannot say similar situation might not arise in REDD+. Therefore, every mechanism has its pros and cons, which should be studied and analyzed carefully to best suit the country's context.

In the current scenario, media has been viewed merely as news reporters. They have simply been used for publishing news. However, this will not work now. If media is not welcomed to be involved in the overall REDD+ process, support of the media cannot be exprected. Media needs to be viewed as a partner rather than merely reporters. Their involvement should be in every phase, from project design to sharing of resources on REDD + . The role of media will be critical in every aspect of REDD+ in Nepal.

\section{SYNTHESIS}

This note summarizes the diverse opinions of the respondents listed in the preceding section. The stakeholders have different and contrasting opinions on the relevance of REDD+ in Nepal. People who agreed on the relevance of REDD+ believed that it would incentivize the communities and government to carry out forest management activities. Others also agreed in this line but with conditional requirements. In their view, REDD+ would be relevant to Nepal if the rights of local communities, indigenous peoples and other marginalized communities such as Dalits, women and poor are kept inviolable and they get fair share of the benefits. They do not believe in free lunch, and, therefore, REDD+ will have conditions. So, if REDD+ is designed to ensure equitable sharing of benefits among the local forest managers, it will benefit the country.

Similarly, there were also views arguing that Nepalese forest stewards, such as communities cannot afford to meet the conditionality of
REDD + such as permanence, leakage, carbon measurements and other technicalities. In this view, REDD+ is more in favour of developed countries than developing ones. It is a scheme offered to have a domination of rich countries over the poor and, therefore, discourages the use of forest resources for development and livelihoods. Though it looks fine in principle, it is not convincing in practice. From this point of view, it can be argued that it is too early to indicate relevance of REDD+ for Nepal. The real benefits of REDD+ would only be determined through its actual implementation.

In response to the question on whether the present REDD+ process addresses the issues related to inclusion, participation, capacity building, etc., most actors opined that the current process is less likely to address those issues. Most of the civil society actors are concerned that participation, inclusion, capacity building and actors' role in REDD+ decision-making have not been adequately considered. They assert that the process itself is not conducive to encouraging participation and engagement of women, Dalits and poor. For them, initial efforts intending to address these issues are gradually becoming naïve and obligatory. Moreover, the current REDD+ process has been perceived to not have fully embraced the aspirations of women, indigenous peoples and other communities, and a lot is to be done to make the process transparent, inclusive and participatory.

The actors, however, have similar responses regarding the REDD+ financing mechanism and the basis of carbon payment. All agreed that the carbon fund should be managed separately and jointly controlled through a multistakeholder body. The mechanism should minimize the transaction costs, for example, fund operating at two levels: national and subnational/local (at district) level. However, the mechanism should ensure that forest managers get equitable benefit. In their view, carbon 
enhancement as well as carbon retention, actions against deforestation and forest degradation, shift from traditional carbonintensive energy use to alternative energy sources, and efforts to contribute to livelihood improvements of the poor and the marginalized should be the basis of carbon payment. Finally, all stakeholders gave specific suggestions that will eventually contribute to the success of REDD+. These suggestions include variety of actions and approaches on awareness raising, capacity building, participation in the REDD+ policy process, advocacy for the rights of the marginalized communities and equitable benefit sharing.

\section{REFERENCES}

Angelsen, A. and McNeill, D. 2012. The Evolution of REDD+. In: A. Angelsen, M. Brockhaus, W.D. Sunderlin, and L.V. Verchot (Eds.), Analysing REDD+: Challenges and Choices, CIFOR, Bogor, Indonesia.

Angelsen, A., Brockhaus, M., Sunderlin, W.D. and Verchot, L. 2012. Analysing REDD+: Challenges and Choices. CIFOR, Bogor, Indonesia.

Busch, J., Godoy, F., Turner, W.R. and Harvey, A. 2010 Biodiversity Co-benefits of Reducing Emissions from Deforestation under Alternative Reference Levels and Levels of Finance. Conservation Letters, 1(2).

CBD. 2010. REDD-plus and Biodiversity Benefits. Convention of Biological Diversity, UNEP/CBD/WS-REDD 1/2 - A Background Document for Global Experts, Workshop on Biodiversity of REDD, 20-23 September, 2010, Nairobi.

Goldtooth, T.B.K. 2010. Why REDD/REDD+ Is NOT a Solution. No REDD: A Reader (http://noredd. makenoise.org/wp-content/uploads/2010/ REDDreaderEN.pdf accessed on 29 July 2013)

Graham, K. 2012. REDD+ and Adaptation: Will REDD+ Contribute to Adaptive Capacity at the Local Level?' Overseas Development Institute. (http://redd-net.org/ files/REDD\%20ADAPTION\%20LONG\%20\%20MASTER\%20final.pdf accessed on 21 July 2013)

Hansen, C.P., Lund, J.F. and Treue, T. 2009. Neither Fast nor Easy: the Prospect of Reduced Emissions from Deforestation and Forest Degradation (REDD) in Ghana. International Forestry Review, 11(4): 439-455.

Khatri, D.B. and Paudel, N.S. 2013. Nepal Getting Ready for REDD? An Assessment of REDD+ Readiness Process in Nepal. Discussion Paper. Kathmandu: ForestAction Nepal.

Phelps, J., Webb, E.L. and Agrawal, A. 2010. Does REDD+ Threaten to Recentralize Forest Governance? Science, 328 312-313.

Purnomo, H., Suyamto, D., Abdullah, L. and Irawati, R.H. 2012. REDD+ Actor Analysis and Political Mapping: An Indonesian Case Study. International Forestry Review, 14(1): $74-89$.

Romijn, E., Herold, M., Kooistra, L., Murdiyarso, D. and Verchot, L. 2012. Assessing Capacities of Non-Annex I Countries for National Forest Monitoring in the Context of REDD+. Environmental Science and Policy, 19-20: 33 48.

Silori, C.S., Frick, S., Luintel, H. and Poudyal, B.H. 2013. Social Safeguards in REDD+: A Review of Existing Initiatives and Challenges. Journal of Forest and Livelihood, 11(2).

Skutsch, M. and De Jong, B.H.J. 2010. The Permanence Debate. Science, 327: 1079.

Stern, N. 2006. The Stern Review: The Economics of Climate Change. Cambridge University Press. 